\title{
ANALISIS PENYEBAB BENCANA ALAM BANJIR YANG ADA DI WILAYAH INDONESIA
}

\author{
Rahmaniah \\ 2010128320006@mhs.ulm.ac.id \\ Program Studi Pendidikan IPS \\ Fakultas Keguruan dan Ilmu Pendidikan \\ Universitas Lambung Mangkurat \\ Banjarmasin
}

\begin{abstract}
Abstrak
Wilayah Indonesia tergolong sebagai salah satu negara yang rawan terhadap bencana, baik bencana alam maupun bencana yang diakibatkan oleh kegiatan manusia itu sendiri. Bencana adalah peristiwa yang sudah sangat akrab dengan masyarakat. Salah satu bencana yang sering kita jumpai yaitu banjir. Bencana banjir yang sudah sering dialami oleh manusia pada dasarnya merupakan hasil dari kegagalan manusia dalam membaca karakter alam. Banjir merupakan suatu bencana yang dapat menimbulkan ketergangguan berlangsungnya kehidupan manusia yang berupa meluapnya volume air pada suatu wilayah yang disebabkan oleh beberapa faktor baik dari manusia itu sendiri maupun alam. Sampai saat ini banjir merupakan suatu masalah yang diperlukan adanya penanganan khusus dari berbagai belah pihak, baik itu dari pemerintah ataupun dari masyarakat. Artikel ini ditulis dengan tujuan untuk mengetahui apa saja penyebab dari terjadinya banjir, kesiapan terhadap banjir, dan upaya dalam mengurangi resiko banjir. Dalam penulisannya menggunakan metode kualitatif bersifat deskriptif, yang artinya data yang dikumpulkan berupa penjabaran dari kata atau kalimat. Artikel ini mengkaji tentang faktor penyebab terjadinya banjir yang ada di wilayah Indonesia serta upaya yang dilakukan dalam mengurangi resiko banjir tersebut.
\end{abstract}

Kata Kunci : bencana, banjir, penyebab banjir, masyarakat.

\section{PENDAHULUAN}

Indonesia merupakan negara yang rawan terhadap berbagai macam bencana, salah satunya adalah bencana alam. Bencana alam dapat diartikan sebagai fenomena alam yang berakibat terjadinya kerusakan dan kehancuran lingkungan sehingga pada akhirnya menimbulkan korban jiwa, kerugian pada harta dan benda serta menimbulkan kerusakan pada bangunan-bangunan yang ada di lingkungan tersebut (D. Arisanty, et al., 2017). 
Di sisi lain, bencana mempunyai arti sebuah peristiwa atau kejadian yang sudah sangat akrab dengan masyarakat kita. Banyak juga yang berpendapat bahwa negara Indonesia surganya bencana. Adapun bencana yang sudah sering kita jumpai salah satunya yaitu banjir.

Populasi yang dimiliki Indonesia sangat besar yaitu berjumlah lebih dari 230 juta jiwa dengan distribusi yang tidak merata, yang terdiri dari berbagai macam humaniora, agama/keyakinan, politik dan budaya, sehingga dapat menyebabkan munculnya konflik horizontal dan vertikal yang pada akhirnya akan mengarah untuk perpindahan. Selain bencana alam, Indonesia juga memiliki potensi munculnya bencana buatan manusia, ini adalah sebagai salah bentuk resiko dari beberapa kegiatan mereka yang dapat merusak lingkungan, termasuk disini adalah kebakaran hutan, penebangan hutan, dan bencana industri (E. Riyanto, et al., 2021).

Suatu peristiwa tergenangnya daratan yang biasanya kering dikarenakan volume air yang meningkat disebut banjir. Banjir bisa terjadi karena air yang meluap disuatu tempat secara berlebihan yang bisa diakibatkan oleh curah hujan yang tinggi, tanggul yang jebol atau karena naiknya permukaan air laut (D. Arisanty, et al., 2017). Bencana alam banjir hampir pasti terjadi disetiap musim penghujan datang (A. Nafarin, et al., 2016). Adapun pengertian banjir berdasarkan Kamus Besar Bahasa Indonesia (KBBI) adalah peristiwa tenggelamnya daratan (yang biasanya kering) disebabkan volume air yang meningkat.

Banjir yang pada hakikatnya proses alamiah dapat menjadi bencana bagi manusia bila proses itu mengenai manusia dan menyebabkan kerugian jiwa maupun materi. Dalam konteks sistem alam, banjir terjadi pada tempatnya. Banjir akan mengenai manusia jika mereka mendiami daerah yang secara alamiah merupakan dataran banjir. Jadi, bukan banjir yang datang, tetapi manusialah yang mendatangi banjir. Apabila hal tersebut dapat kita terima, maka bencana banjir yang dialami manusia sebenarnya adalah buah dari kegagalan manusia dalam membaca karakter alam. Kegagalan manusia membaca apakah suatu daerah aman atau tidak untuk didiami. Misalnya, kegagalan manusia membaca karakter suatu daerah sehingga tidak mengetahui daerah tersebut merupakan daerah banjir. Banjir adalah suatu bencana yang mengganggu kehidupan manusia berupa genangan air dari yang terkecil sampai terbesar yang disebabkan faktor-faktor baik manusia maupun alam atau aliran air yang tinggi, dan tidak tertampung oleh aliran sungai sehingga air itu meluap ke daratan yang lebih rendah. Maka adapun ditulisnya artikel ini adalah dengan tujuan untuk mengetahui apa saja penyebab dari terjadinya banjir, kesiapan terhadap banjir, dan upaya dalam mengurangi resiko banjir. 


\section{METODE}

Dalam penelitian kali ini metode yang digunakan yaitu metode kualitatif yang bersifat deskriptif. Artinya metode penelitian ini menggambarkan data dengan kalimat kemudian dipisah menurut masing-masing kategori untuk memperoleh kesimpulan. Hal ini berdasarkan pendapat Arikunto (1988:193). Oleh karena itu penelitian ini menggunakan metode kualitatif karena penelitian ini datanya tidak berbentu angka, tetapi berbentuk kata atau kalimat yang berupa penjabaran dari deskripsi. Pada dasarnya penelitian adalah mengumpulkan data yang dianalisis. Pada penelitian kali ini metode yang dipakai yaitu deskriptif. Sebuah metode yang efektif yang dipakai untuk mendeskripsikan sebuah fenomena-fenomena yang terjadi di suatu wilayah. Semua data diperoleh dari situs pencarian google scholar. Artikel yang diperoleh kemudian dibaca dari abstrak hingga kesimpulan untuk mendapatkan informasi yang terkait dengan banjir.

\section{PEMBAHASAN}

Banjir masih menjadi masalah yang sampai sekarang ini masih perlu adanya penanganan khusus dari berbagai belah pihak, yaitu baik dari pemerintah maupun masyarakat itu sendiri. Bencana banjir bukanlah suatu masalah yang ringan. Banjir bisa saja terjadi akibat naiknya volume air/permukaan air dikarenakan curah hujan yang tinggi atau curah hujan yang di atas normal, tanggul/bendung yang jebol, dan bisa juga terjadi akibat terhambatnya aliran air di tempat lain. Penyebab banjir di Indonesia sedikitnya ada lima faktor penting yaitu faktor hujan, faktor kesalahan perencanaan pembangunan alur sungai, faktor tidak adanya retensi Daerah Aliran Sungai (DAS), faktor pendangkalan sungai, dan faktor kesalahan tata wilayah serta pembangunan sarana dan prasarana.

Hampir disetiap musim penghujan tiba maka terjadilah banjir. Banjir pun datang tanpa mengenal tempat dan siapa saja yang tinggal atau menghuni tempat tersebut. Banjir bisa terjadi di wilayah pemukiman, persawahan, ladang, jalan, tambak, bahkan juga dapat terjadi di perkotaan. Tidak ada yang dapat menghindari bencana banjir, tetapi dampak dari banjir dapat diminimalisir dengan cara penaggulangan terhadap banjir. Berbagai macam dampak dapat ditimbulkan akibat bencana banjir, diantaranya yaitu: adanya korban jiwa, rumah warga menjadi kotor, warga dapat terserang berbagai macam penyakit seperti penyakit kulit, diare, dan lain-lain, terjadinya kerusakan bangunan-bangunan, kegiatan ekonomi warga jadi macet, jalan jadi berlubang, bahkan hingga trauma yang bisa saja dialami oleh warga atau masyarakat. 
Banyak sekali dampak dan pengaruh yang ditimbulkan akibat banjir bagi masyarakat. Selain dari rumah yang mengalami kerusakan, harta benda yang hanyut terbawa derasnya air banjir, tidak jarang banjir juga dapat berakibat menimbulkan korban jiwa . Oleh karena hal tersebut maka banyak masyarakat yang mengungsi ke tempat yang lebih tinggi, lebih aman seperti ke tempat pengungsian atau bahkan ke tempat karib kerabat terdekat. Selain daripada hal itu, penyebab banjir yang terjadi juga dapat karena masyarakat yang kurang menyadari betapa pentingnya untuk menjaga lingkungan sekitar. Mulai dari kebiasaan masyarakat membuang sampah ke sungai, sehingga banyak sampah yang terdapat di sungai ditambah lagi dengan sistem drainase yng kurang baik dalam menyerap air sehingga menimbulkkan genangan dan menimbulkan banjir, serta kurangnya daya serap pohon disepanjamg aliran sungai. Melihat kebiasaan masyarakat yang membuang sampah ke sungai, maka hal tersebut tentunya dapat menyebabkan pendangkalan sehingga secara otomatis hal tersebut sangat berengaruh terhadap timbulnya banjir di suatu wilayah.

Fenomena alam yang berubah (topografi) ataupun tingginya curah hujan juga dapat memicu penyebab terjadinya banjir (Apriyanza, Amri, and Gunawan 2018), serta kondisi geografisnya juga bisa menjadi pengaruh terjadinya bencana banjir. Ruang terbuka hijau di beberapa wilayah yang ada di Indonesia sangatlah kurang, sehingga penyerapan air ke dalam tanahpun juga kurang. Melihat kondisi yang seperti ini, maka bukan hanya pemerintah yang harus bergerak mengatasi banjir yang hampir terjadi setiap musim hujan ini, tetapi juga harus ada kesadaran dari diri tiap individu atau masyarakat untuk menjaga kebersihan lingkungan sekitar dan menjaga serta melestarikan kehijauan lingkungan masing-masing. Saat ini di beberapa wilayah yang ada di Indonesia sudah penuh dengan bangunan-bangunan, sehingga banyak sampah rumah tangga yang dihasilkan yang kemudian malah dibuang ke sungai sekitar (R. Afrian, 2021).

Kurangnya pemahaman masyarakat tentang sistem Drainase yang juga berpengaruh terhadap penjagaan lingkungan, dalam pelaksaan sistem ini tidak semudah yang kita bayangkan, apalagi masih banyak masyarakat awam yang kadang susah diberikan masukan, pemahaman ataupun pengertian. Aliran pembuangan limpahan air secara alami ataupun buatan yang biasanya di bawah permukaan dari suatu tempat disebut drainase. Drainase ini dapat dilakukan dengan cara mengalihkan, mengalirkan, atau membuang limpahan air. Tetapi dengan cara drainase ini bukan berarti bisa langsung menghilangkan banjir tersebut, dalam hal ini masyarakat juga wajib menjaga kebersihan apalagi yang mengalir kearah saluran drainase. Mengapa demikian, karena apabila saluran drainase mengalami penumpukan 
sampah yang sangat berlebihan maka dapat juga menyembabkan luapan air. Artinya kita harus bekerja sama untuk menjaga lingkungan demi kenyamanan bersama. Tata ruang ternyata juga memiliki pengaruh terhadap banjir. Infrastruktur yang sudah padat, sehingga tidak terpadatkan oleh tumbuhan yang seharusnya bisa menyerap air yang berlebihan disitu juga hilang. Kita hanya menebang pohon, tetapi tidak menanamnya kembali, kita hanya membangun rumah, tetapi tidak memikirkan lingkungan sekitar kita tinggal.

Banyaknya rumah disuatu daerah berarti menandakan kalau di dearah tersebut banyak manusianya, yang mana pastinya akan menghasilkan sampah rumah tangga yang tidak sedikit lalu dibuang ke lingkungan sekitar. Mungkin untuk sekarang kita tidak bisa menghentikan banjir tahunan ini, tetapi kita bisa meminimalisir atau mengecilkan luapan yang berlebihan dengan cara penanaman penghijauan (penanaman pohon kembali), tidak menggunakan plastik yang berlebihan, mengolah sampah rumah tangga, tidak membuang apapun kearah aliran air, membukan saluran drainase (Afrian \& Zukya, 2019), dan memperbaiki tata ruang lingkungan. Kemudian dari perilaku dan tindakan masyarakat masih kurang kesadaran akan kebersihan lingkungan, sehingga masih banyak masyarakat yang tidak memperdulikan hal tersebut. Padahal kepedulian akan lingkungan itu sangat penting untuk keselamatan kita semua. Maka dari itu marilah kita selalu mencintai lingkungan kita jadilah manusia yang peduli akan lingkungan, sehingga alam pun akan senantiasa menjaga kita.

Berdasarkan pernyataan Dodon (2013) dan berbagai indikator yang di kemukakan oleh ISDR (2005), Sutton dan Tierney (2006), dan Perry dan Lindell (2008), umumnya mencakup beberapa hal yang sama yaitu :

a) Pengetahuan dan Sikap Terhadap Bencana

Pengetahuan terhadap bencana merupakan alasan utama seseorang untuk melakukan kegiatan perlindungan atau upaya kesiapsiagaan yang ada. Indikator pengetahuan dan sikap individu/rumah tangga merupakan pengetahuan dasar yang semestinya dimiliki oleh individu meliputi pengetahuan tentang bencana, penyebab dan gejala-gejala, maupun apa yang harus dilakukan bila terjadi banjir.

b) Rencana Tanggap Darurat

Rencana tanggap darurat adalah suatu rencana yang dimiliki oleh individu atau masyarakat dalam menghadapi keadaan darurat di suatu wilayah akibat bencana alam. Rencana tanggap darurat sangat penting terutama pada hari pertama terjadi bencana atau masa dimana bantuan dari pihak luar belum datang. 
c) Sistem Peringatan Dini

Sistem peringatan meliputi tanda peringatan dan distribusi informasi jika akan terjadi bencana. Sistem yang baik ialah sistem dimana masyarakat juga mengerti informasi yang akan diberikan oleh tanda peringatan dini tersebut atau tahu apa yang harus dilakukan jika suatu saat tanda peringatan dini bencana berbunyi/menyala.

d) Sumberdaya Mendukung

Indikator ini umumnya melihat berbagai sumber daya yang dibutuhkan individu atau masyarakat dalam upaya pemulihan atau bertahan dalam kondisi bencana atau keadaan darurat. Sumberdaya mendukung berasal dari internal maupun eksternal dari wilayah yang terkena bencana. Sumber daya menurut Sutton dan Tierney dibagi menjadi 3 bagian yaitu sumber daya manusia, sumber daya pendanaan/logistik, dan sumber daya bimbingan teknis dan penyedian materi.

e) Modal Sosial

Modal sosial sering diartikan sebagai kemampuan individu atau kelompok untuk bekerja sama dengan individu atau kelompok lainnya. Masyarakat atau individu yang memiliki ikatan sosial yang lebih baik antara satu dengan yang lainnya akan lebih mudah dalam melakukan kesiapsiagaan yang ada. Modal sosial yang baik diantara masyarakat di wilayah yang rentan terhadap bencana akan mengurangi kerentanan itu sendiri.

Lajunya perkembangan yang ada di wilayah perkotaan dapat dikarenakan lajunya pertumbuhan penduduk yang tinggi. Dan lajunya perkembangan ini mengakibatkan kebutuhan lahan untuk dijadikan sebagai tempat tinggal di wilayah perkotaan terus-menerus mengalami peningkatan dan hal ini berimplikasi dari pertumbuhan penduduk. Menurut Suprayogi, dkk (2019) menyatakan bahwa rencana tata ruang berupaya mengatur peruntukkan lahan walaupun dengan status kepemilikan dari lahan tersebut adalah pribadi untuk kepentingan umum. Lebih lanjut Suprayogi, dkk (2019) menjelaskan bahwa beberapa hal yang harus dipertimbangkan dalam penetapan guna lahan adalah daya dukung lahan dan daya tampung lahan (kondisi alamiah), penggunaan lahan eksisting, ketersediaan lahan, harmonisasi ruang dengan penggunaan lahan lainnya, infrastruktur, tren perkembangan (demografi dan kawasan), pertumbuhan ekonomi dan lain sebagainya.

Menurut Jayadinata (1999) dalam Suprayogi, dkk (2019) menyatakan bahwa polapenggunaan lahan akan semakin kompleks, sebab kegiatan-kegiatan bergerak dinamis. Tata guna lahan mengandung pengertian mengatur ruang kegiatan masyarakat agar lahan 
dapat digunakan secara efisien dan terencana. Intensitas penggunaan lahan dan lokasi penggunaan lahan sangat mempengaruhi pergerakan penduduk dan barang dalam suatu kawasan. Adapun factor-faktor yang mempengaruhi terhadap perkembangan pola penggunaan lahan adalah : (a) topografi; (b) penduduk; (c) aksesibilitas; (d) sarana dan prasarana; (e) daya dukung lahan.

Kemudian perubahan fungsi lahan yang terjadi di wilayah perkotaan dari nonterbangun menjadi terbangun bertalian dengan perluasan wilayah kota sebagai wujud fisik dan desakan urbanisasi. Latar belakang pertumbuhan kota secara fisik memiliki karakteristik yang beragam dan adanya dampak yang bersifat keruangan pada hakikatnya sama, yaitu cenderung berkompetisi dalam penggunaan lahan di daerah pinggiran atau sekitar kota yang sebelumnya merupakan lahan pertanian (Suprayogi, dkk, 2019).

Dengan tingginya pertumbuhan penduduk, maka akan sangat mempengaruhi daya dukung lingkungan terhadap kehidupan manusia, hal tersebut dapat dilihat dari tingginya penggunaan lahan yang digunakan sebagai tempat tinggal. Karena penggunaan lahan yang tinggi tersebut guna mengatasi masalah penduduk, maka dapat mengurangi kawasan atau daerah resapan air perkotaan. Menurut Suprayogi, dkk (2019) menyatakan bahwa guna lahan akan mempengaruhi terhadap besarnya presentase jumlah air yang dapat meresap ke dalam tanah. Pada lahan yang tertutup bangunan, volume air hujan yang mengalir di permukaan akan lebih besar dibandingkan dengan air yang meresap ke dalam tanah.

Bencana banjir memang tidak dapat dihindari, tetapi dampaknya dapat diminimalisir dengan cara penaggulangan terhadap banjir. Adapun strategi untuk mengurangi banjir yang dikemukakan oleh Robert J. Kodoatie dan Roestam Sjarief (2012), sebagai berikut:

1. Bendungan dan waduk

2. Tanggul dan penahan banjir

3. Peningkatan kapasitas saluran drainase atau sungai

4. Tindakan-tindakan perbaikan lahan

5. Penahanan di suatu lokasi (on-site detention)

Banjir sering kali menjadi masalah bagi sebagian warga masyarakat, terutama masyarakat yang tinggal di daerah dataran rendah maupun di bantaran sungai. Jarak rumah warga dengan sungai yang terlalu dekat, menjadi faktor utama yang mengakibatkan terjadinya banjir di pemukiman. Sebagian warga ada yang sudah mengetahui bagaimana cara menyelamatkan diri ketika banjir datang secara tiba-tiba, sebagian juga ada yang belum 
mengetahui cara untuk menyelamatkan diri. Warga yang telah banyak mengetahui tentang kesiapsiagaan menghadapi bencana banjir, mereka akan menyiapkan alat untuk mengevakuasi dirinya sendiri maupun keluarganya.

Adapun menurut Undang-Undang Nomor 24 Tahun 2007, Mitigasi merupakan serangkaian upaya untuk mengurangi resiko bencana melalui pembangunan fisik maupun upaya penyadaran masyarakat dan peningkatan kemampuan menghadapi ancaman bencana. Upaya yang harus dilakukan untuk melakukan mitigasi banjir dan menurunkan risiko jatuhkan korban jiwa kerugian moril dan materil. Yang harus dilakukan dengan melakukan mitigasi secara Struktural dan Non struktural. Mitigasi secara struktural adalah mitigasi yang lebih menekankan pada fisik pembangunan. Pada saat ini pun upaya yang dilakukan mitigasi bencana masih dengan mengandalkan kegiatasn fisik. Seperti membangunan tanggul pada daerah yang rawan banjir, atau bisa juga dengan mengisi karung dengan pasir dan batu, yang selanjutnya bahan tersebut akan di gunakan sebagi pondasi pembuatan tanggul secara swadaya oleh masyarakat sekitar. Pembangunan tanggul di pingirr sungai ini pada pada dasarnya bertujuan uintuk mencegah meluapnya air dengan ketinggian tertentu yang dapat memasuki daerah dataran banjir. Kemudian dapat dilakukan upaya mitigasi secara non struktur, kegiatan nonstruktur ini memiliki tujuan untuk dapat menghidarkan dan lebih menekankan seberapa besarnya masalah yang dapat ditimbulkan oleh banjir. Masyarakat bisa mengatur pemberdayaan lahan di daerah DAS dan banjir (R. Afrian 2021).

Kemudian dengan adanya kegiatan tidak membuang sampah ke sungai, dengan melakukan kampaye seperti itu, supaya masyarakat lebih sadar akan kebersihan sungai. Supaya sampah yang dapat mengotori sungai dapat menyebabkan pendangkalan sungai, kemudian membuat sungai menjadi kotor, dan menhambat aliran air sungai itu sendiri (Apriyanza et al., 2018). Selain itu dengan keadaan sungai yang demikian, di tambah lagi dengan keadaan lingkungan di daerah hulu yang sudah mengalami pengrusakan akibat penebangan hutan secara liar tanpa melakukan reboisasi (penanaman kembali), tentukan hal tersebut dapat menjadi ancaman tersendiri khususnya bagi daerah hilir. Maka dari itu perlunya menjaga kebersihan sungai agar kita semua terhindar dari bencana banjir yang kapan saja bisa datang.

\section{SIMPULAN}

Becana merupakan suatu peristiwa yang terjadi di alam yang bisa disebabkan oleh alam, non alam maupun manusia, hal tersebut tentunya akan banyak sekali menimbulkan 
kerugian harta benda dan juga menimbulkan korban jiwa. Banjir adalah keadaan dimana air yang tergenang didataran dengan volume yang banyak. Mitigasi adalah serangkaian kegiatan yang di lakukan untuk mengurangi risiko bencana. Upaya yang dapat dilakukan untuk melakukan mitigasi bencana adalah dengan melakukan mitigasi secara struktur dan non struktur. Mitigasi secara struktur mitigasi yang lebih menekankan pada pembangunan fisik, seperti pembangunan tanggul, waduk dan lain sebagainya. Kemudian mitigasi secara non struktur, mitigasi yang di lakukan dengan melakukan pemberdayaan untuk menghindari bencana terkhusus bencana banjir.

\section{DAFTAR PUSTAKA}

Abbas, E. W. (2015). Pendidikan IPS berbasis kearifan lokal. WAHANA Jaya Abadi.

Afrian, R. (2021). Kajian Mitigasi Terhadap Penyebab Bencana Banjir di Desa Sidodadi Kota Langsa. Jurnal Georafflesia: Artikel Ilmiah Pendidikan Geografi, 5(2), 165-169.

Erlia, D., Kumalawati, R., \& Aristin, N. F. (2017). Analisis kesiapsiagaan masyarakat dan pemerintah menghadapi bencana banjir di Kecamatan Martapura Barat Kabupaten Banjar. JPG (Jurnal Pendidikan Geografi), 4(3).

Handy, M. R. N., Mutiani, M., Putra, M. A. H., Syaharuddin, S., \& Putro, H. P. N. (2021). Adaptation of Riverbanks Community to Urban Green Open Space Development. The Innovation of Social Studies Journal, 2(2), 127-134.

Nafarin, A., Adyatma, S., Arisanty, D., \& Riadi, S. (2017). MODEL PENGELOLAAN DAERAH RAWAN BENCANA BANJIR BERBASIS MASYARAKAT DI KABUPATEN HULU SUNGAI TENGAH PROVINSI KALIMANTAN SELATAN.

Norhayati, N., Abbas, E. W., \& Putra, M. A. H. (2019). Social Interaction Pattern Jelai Riverbanks South Basirih. The Innovation of Social Studies Journal, 1(1), 12-20.

Razikin, P., Kumalawati, R., \& Arisanty, D. (2017). Strategi Penangulangan Bencana Banjir Berdasarkan Persepsi Masyarakat Di Kecamatan Barabai Kabupaten Hulu Sungai Tengah. JPG (Jurnal Pendidikan Geografi), 4(1). 
Riyanto, E., Widyananto, E., Aziz, U. A., Taufik, M., \& Setiawan, A. (2021). SOSIALISASI PENYEBAB DAN KESIAPSIAGAAN BENCANA BANJIR DI DESA SIDOMULYO KECAMATAN BUTUH KABUPATEN PURWOREJO.

Rusmaniah, R., Mardiani, F., Handy, M. R. N., Putra, M. A. H., \& Jumriani, J. (2021). Social Services Based on Institutional for Youth Discontinued School. The Innovation of Social Studies Journal, 2(2), 151-158.

Rusmaniah, R. PEMBINAAN MORAL REMAJA PUTUS SEKOLAH PADA PSBR BUDI SATRIA PROVINSI KALIMANTAN SELATAN. Jurnal Socius, 6(02).

Sulaiman, M. E., Setiawan, H., Jalil, M., Purwadi, F., Brata, A. W., \& Jufda, A. S. Analisis Penyebab Banjir di Kota Samarinda. Jurnal Geografi Gea, 20(1), 39-43.Banjdi Kota Samarinda. Jurnal Geografi Gea, 20(1), 39-43. 